\title{
Regional Age Variation of the Southern African Mantle: Significance for Models of Lithospheric Mantle Formation
}

Carlson, R.W. ${ }^{1}$, Pearson, D.G. ${ }^{2}$, Boyd, F.R. ${ }^{1}$, Shirey, S.B. ${ }^{1}$, Irvine, G. ${ }^{2}$, Menzies, A.H. ${ }^{3}$, and Gurney, J.J. ${ }^{3}$

1. Carnegie Institution of Washington, 5241 Broad Branch Road N.W., Washington, D.C. 20015, USA

2. Department of Geological Sciences, Durham University, South Road, Durham, DH1 3LE, UK

3. Department of Geological Sciences, University of Cape Town, Rondebosch 7700, South Africa

Southern Africa is unique in its abundance and wide-spread distribution of alkalic-ultramafic diatremes that have brought samples of the lithospheric mantle to the surface in the form of peridotite xenoliths. These xenoliths have been shown to be almost ubiquitously depleted in their magmaphilic elements, particularly $\mathrm{Ca}, \mathrm{Al}$ and $\mathrm{Fe}$, compared to any estimate of fertile mantle (Boyd and Mertzman, 1987). Since this depletion results in an assemblage that is less dense than fertile mantle (Boyd and McCallister, 1976; Jordan, 1979), this compositional characteristic has been given primary credit for the existence of thick, seismically fast, lithospheric mantle keels to Archean cratons (Jordan, 1988).

The age distribution of the lithospheric mantle is critical in trying to understand the mechanism of formation of the continental crust and lithospheric mantle. If formed as a result of extensive melting of a hot mantle plume (Herzberg, 1993), one might expect a relatively narrow age range for lithospheric maierials clustering close to the time of the plume event. Alternatively, "stacking" models involving the subduction/obduction of either oceanic plates (deWit et al., 1992) or island arcs (Rudnick, 1995) could produce both lateral and vertical variations in age depending on the age of the materials being added to the "stack". Growth of the lithospheric mantle by simple conductive cooling, as occurs in the ocean basins, should produce a downward younging age pattern.

The antiquity of the mantle beneath cratons was first indicated by the old ages obtained for silicate (Richardson et al., 1984) and sulfide (Kramers, 1979) inclusions in diamonds, but these ages are not directly applicable for determining the age of the peridotites since they are obtained on inclusions in a trace, probably metasomatic, phase (diamond). In addition, at least for the silicate inclusion Sm-Nd data, the inclusion ages date an event of incompatible element enrichment that must post-date the depletion characterizing the major element composition of the peridotites. In contrast, the Re-Os isotopic system can be applied directly to whole-rock peridotite samples and has been shown to primarily track the depletion history of the rock rather than later metasomatic events (Walker et al., 1989; Carlson and Irving, 1994; Pearson et al., 1995a; Pearson et al., 1995b). Whole rock Redepletion ages for peridotites, however, are model ages; based on a model peridotite evolving with chondritic ( = fertile mantle) Re/Os that experiences complete Re loss in a single event and remains Re-free until its transport to the surface. This simplistic, single-stage, model works surprisingly well when applied to cratonic peridotites, but Re-Os model ages can be affected by either incomplete Re removal and/or later Re-enrichment during the multi-stage chemical evolution experienced by the cratonic mantle. 
At this time, Re-Os data are available from 9 on-craton localities (Kimberley floors, Newlands, Finsch, Jagersfontein, Matsoku, Liquobong, Letsang-la-terae, Premier, and Venetia) and 2 off-craton localities (Gibeon and East Griqualand). Peridotites from both on- and off-craton localities show considerable $(>1 \mathrm{Ga}$ ) age variation between individual samples, including between the xenoliths from a single kimberlite. Whether the magnitude of this variation represents the true age range of lithospheric materials, the oversimplistic nature of the Re-depletion model age calculation, or metasomatic perturbation of the Re-Os system remains to be answered.

The most obvious age distinction in the data is between the on- and off-craton localities. The average Re-depletion model age for peridotite xenoliths from off-craton localities (Pearson et al., $1998)$ is $1.6+/-0.4 \mathrm{Ga}(\mathrm{n}=16$, range 1.1 to $2.2 \mathrm{Ga}$ ) compared to $2.5+/-0.5 \mathrm{Ga}(\mathrm{n}=42$, range 1.2 to $3.6 \mathrm{Ga}$ ) for on-craton localities. The similarity of the mean age of peridotites from off-craton localities to the age of the mid-Proterozoic mobile belts through which they erupt indicates that formation of lithospheric keels is not restricted to the Archean, though cratonic keels may extend to greater depth than those under post-Archean crust. The sharp transition in ages between the Archean peridotites contained in Northern Lesotho kimberlites compared to the primarily Proterozoic peridotites from the nearby off-craton East Griqualand kimberlites indicates that the Archean materials characterizing the craton lithosphere were not extensively interleaved with the lithosphere of the surrounding mobile belts during their accretion to the craton. Similarly, the lack of Archean age peridotite xenoliths from off-craton localities indicates that the Archean lithosphere has not flowed laterally beneath the surrounding mobile belts over time.

Within the on-craton localities, there is no resolvable age variation with depth of origin of the peridotites. The average Re-depletion model age for spinel peridotites is $2.5+/-0.3 \mathrm{Ga}$ ( $\mathrm{n}=12$, range $=2.0$ to $3.0 \mathrm{Ga}$ ) compared to an average of $2.6+/-0.5 \mathrm{Ga}(\mathrm{n}=31$, range $=1.2$ to $3.6 \mathrm{Ga})$ for low-temperature garnet peridotites. High-temperature garnet peridotites give a slightly younger mean Re-depletion age $(2.3+/-0.8 \mathrm{Ga}, \mathrm{n}=6$, range $=1.3$ to $3.5 \mathrm{Ga})$. This age still requires the high-T peridotites to be parts of the ancient, Re-depleted, lithospheric keel to the craton rather than originating from the underlying asthenosphere. The slightly younger age of the high-T peridotites could reflect later (late Archean to early Proterozoic) underplating of the keel, but also could indicate the influence of increased metasomatism in the high- $T$ samples or simply the fact that only 6 high- $T$ samples have been analyzed at this point.

Regionally across the Kaapvaal craton, there is a statistically unresolved suggestion of a westward younging of the mantle that would match that of the overlying crust. Peridotites from the westernmost localities (Finsch, Kimberley and Newlands) give mean Re-depletion ages of 2.4, 2.6 and $2.7 \mathrm{Ga}$, respectively, while peridotites from the Northern Lesotho kimberlites give a slightly higher mean age of $2.9 \mathrm{Ga}$ with 4 of 7 samples showing Re-depletion ages of $3 \mathrm{Ga}$ or greater.

An exception to this trend occurs at Premier where the mean peridotite Re-depletion age is a relatively young $2.3+/-0.6 \mathrm{Ga}$ and 6 of 12 samples give Re-depletion ages between 2.0 and $2.3 \mathrm{Ga}$. Premier is the only locality examined so far that lies within the boundary of the $2.05 \mathrm{Ga}$ Bushveld 
intrusion. The circa $2 \mathrm{Ga}$ peridotite ages obtained at Premier overlap the Bushveld age and suggest that much of the mantle sampled as xenoliths in the Premier kimberlite may be the residue left by extraction of Bushveld melts. The alternative, that these peridotites obtained their young age through interaction with, or incorporation of, Bushveld melts is contradicted by the observation that the Premier peridotites have bulk elemental compositions similar to other cratonic peridotites (Boyd and Mertzman, 1987; Boyd et al., 1997) and routinely have among the lowest Re/Os measured for southern African peridotites. Since the Bushveld, and most other mafic melts, would be expected to have much higher Re/Os than residual peridotite, the low Re/Os observed for the Premier peridotites suggests that the circa $2 \mathrm{Ga}$ ages obtained are not caused by metasomatism of Archean peridotite, but instead reflect new lithospheric mantle added to the craton during the Bushveld event.

\section{References}

Boyd, F. R., and McCallister, R. H., 1976, Densities of fertile and sterile garnet peridotites: Geophys. Res. Lett., v. 3, p. 509-512.

Boyd, F. R., and Mertzman, S. A., 1987, Composition and structure of the Kaapvaal lithosphere, Southern Africa, in Mysen, B. O., ed., Magmatic Processes: Physicochemical Principles, The Geochemical Society, p. 3-12.

Boyd, F. R., Pokhilenko, N. P., Pearson, D. G., Mertzman, S. A., Sobolev, N. V., and Finger, L. W., 1997, Composition of the Siberian cratonic mantle: evidence from Udachnaya peridotite xenoliths: Contrib. Mineral. Petrol., v. 128, p. 228-246.

Carlson, R. W., and Irving, A. J., 1994, Depletion and enrichment history of subcontinental lithospheric mantle: an $\mathrm{Os}, \mathrm{Sr}, \mathrm{Nd}$ and $\mathrm{Pb}$ isotopic study of ultramafic xenoliths from the northwestern Wyoming Craton: Earth Planet. Sci. Lett., v. 126, p. 457-472.

deWit, M. J., Roering, C., Hart, R. J., Armstrong, R. A., Ronde, C. E. J. d., Green, R. W. E., Tredoux, M., Peberdy, E., and Hart, R. A., 1992, Formation of an Archaean continent: Nature, v. 357, p. 553-562.

Herzberg, C. T., 1993, Lithosphere peridotites of the Kaapvaal craton: Earth Planet. Sci. Lett., v. 120, p. 13-29.

Jordan, T. H., 1979, Mineralogies, densities and seismic velocities of garnet lherzolites and their geophysical implications, in Boyd, F. R., and Meyer, H. O. A., eds., The Mantle Sample: Inclusions in Kimberlites and Other Volcanics: Washington, American Geophysical Union, p. 1-13.

Jordan, T. H., 1988, Structure and formation of the continental tectosphere: J. Petrol., v. 29, p. 11-37.

Kramers, J. D., 1979, Lead, uranium, strontium, potassium and rubidium in inclusion-bearing diamonds and mantlederived xenoliths from southern Africa: Earth Planet. Sci. Lett., v. 42, p. 58-70.

Pearson, D. G., Carlson, R. W., Shirey, S. B., Boyd, F. R., and Nixon, P. H., 1995a, Stabilization of Archean lithospheric mantle: a Re-Os isotope study of peridotite xenoliths from the Kaapvaal craton: Earth Planet. Sci. Lett., v. 134 , p. $341-357$.

Pearson, D. G., Snyder, G. A., Shirey, S. B., Taylor, L. A., Carlson, R. W., and Sobolev, N. V., 1995b, Archaean Re-Os age for Siberian eclogites and constraints on Archaean tectonics: Nature, v. 374, p. 711-713.

Richardson, S. H., Gurney, J. J., Erlank, A. J., and Harris, J. W., 1984, Origin of diamonds in old enriched mantle: Nature, v. 310 , p. $198-202$.

Rudnick, R. L., 1995, Making Continental Crust: Nature, v. 378, p. 571-578.

Walker, R. J., Carlson, R. W., Shirey, S. B., and Boyd, F. R., 1989, Os, Sr, Nd, and Pb isotope systematics of southern African peridotite xenoliths: Implications for the chemical evolution of subcontinental mantle: Geochim. Cosmochim. Acta, v. 53, p. 1583-1595. 